\title{
Development Innovations through Entrepreneurial Microfinance and the Attempt to Achieve the United Nations Millennium Development Goals in Bangladesh
}

\author{
Saleh Ahmed
}

\begin{abstract}
As one of the countries in the Global South, Bangladesh has experienced numerous development challenges since its liberation in 1971. Bangladesh has showcased how to fight against poverty and to initiate meaningful change and development in human lives. Nobel Prize (2006) winner Grameen Bank is one of the popular development innovations in the country. Since the beginning of this Bank in the early 1970s, microfinance and entrepreneurship development with small amounts of money have proliferated to nearly every corner of the globe with the paramount goal of alleviating global poverty and ensuring human development. Like all other new social science techniques, the societal revolution brought about by microfinance expansion has left substantial room for refinement and further support by empirical evidence. This article critically evaluates a non-governmental initiative to empower extremely poor women through entrepreneurial microfinance, and examines the socioeconomic impacts in achieving the United Nations Millennium Development Goals (UNMDGs). This article covers both primary and secondary information. The aim is to demonstrate how countries of the Global South can use carefully designed microfinance projects to address major development challenges and meaningfully contribute to creating a more equal, humane society.
\end{abstract}

Keywords: Bangladesh, extremely poor women, microfinance, SMEs, UNMDGs

\section{BACKGROUND}

In the recent generations we have experienced enormous advances and development among the human societies, but still a large portion of world population is living in and struggling with poverty. With transitional economies and weak political institutions, many countries in Global South are suffering from poverty, inequality and exclusion. In this context, microfinance has appeared as one of the effective development instruments to address these societal challenges. At the beginning of 1970s, microfinance meant giving a small amount of credit money to the poor people, but now the impact it produces goes beyond just business loans at hand. Poor people use the financial resources for various purposes ranging from their daily living to expenses like entrepreneurship development or the associated costs for education or health. Presently, in most of the cases, micro-financial services include services like loans, savings facilities, insurance, transfer payments, and even micro-pensions or micro-insurance. Evidence from the millions of microfinance beneficiaries around the world shows that access to financial services helps poor people to increase their household incomes, build their assets, develop social networks and reduce their vulnerability to different forms of manmade or natural crises. Microfinance has also had positive impacts on better nutrition intake and

Saleh Ahmed is a doctoral student in the Department of Sociology, Social Work and Anthropology at Utah State University.

Copyright @ 2012 Advances in Social Work Vol. 13 No. 2 (Summer 2012), 358-374 
improved health outcomes, such as higher immunization rates. Several experiences demonstrate that access to microfinance helps people to plan for their future and also acts as an incentive to send their children to schools. Microfinance has positive impacts on confidence building and helps women to confront gender inequalities (CGAP, 2002).

Confronting many of the human development challenges in the Global South, 189 world leaders signed the Millennium Declaration in September 2000, popularly known as the United Nations Millennium Development Goals (UNMDG). UNMDG aim was a world free of hunger, poverty and disease, and 'Human Dignity for all' (Pimple, 2009). The Millennium Goals address multiple dimensions of poverty, including income poverty, hunger, and disease; lack of education, infrastructure and shelter; and gender exclusion and environmental degradation. These goals are particularly important in the Global South, where the countries and societies are struggling with different forms of human suffering. UNMDGs in a way initiate change in human lives so that they can prosper and live with dignity. Microfinance can play a critical role in framing the solution in this context. It can enhance access to capital and at the same time can help to develop entrepreneurial capacity, and this enhanced capacity can contribute to achieve the millennium development goals. The initial timeline for these goals are 2015, when the world leaders would like to review how their development plans and goals have positively impacted the world population. The government of Bangladesh has signed onto these goals. In recent years, the Bangladeshi Government's Annual Development Plans (ADPs) are aligned with the stated development targets of UNMDGs.

In countries like Bangladesh, where a majority of the population are poor, it is very difficult for the traditional financial institutions to ensure loans for most loan applicants. For the poor it is most desirable if they can get collateral-free working capital loans to initiate their small and medium size enterprises (SMEs). In low-income developing countries, entrepreneurship and SMEs have been recognized as important factors that contribute to the local employment creations and economic development. SMEs and entrepreneurial microfinance are closely intertwined. Without entrepreneurial microfinance it is difficult for the poor to initiate SMEs, and when they have both, the entrepreneurial microfinance and SMEs, they can work to increase their income and employability, accumulate assets, and contribute to their socioeconomic inclusion. All these factors together not only contribute to the lives of the beneficiaries, but also create multiplier impacts on the community. It creates local business and generates local consumer demand. In a typical rural community, SMEs also contribute to developing social relations or networks, civic engagement, community solidarity, and social capital (Ssewamala, Lombe, \& Curley, 2006). Promotion of SMEs also work function as the 'safety net' for unemployed people, particularly in the societies where unemployment insurance is not available (Tokman, 1996).

In the low-income developing countries during droughts, grain stock may be depleted by ongoing consumption to the extent that little is left over for the next planting cycle, effectively cutting off the possibility of future consumption (McKenzie \& Woodruff, 2006). This creates food security problems and can contribute to generate a regional poverty trap, and in turn this poverty trap creates a continual dependence on external injections of resources such as food aid without the potential for a community to reach 
endogenously stable consumption/production equilibrium (Adams \& Raymond, 2008; McKenzie \& Woodruff, 2006). Therefore, it could be a way to break the poverty trap by encouraging SMEs through the entrepreneurial microfinance among the poor for ensuring their productivity surplus (Varghese, 2005). This is the core argument why a country like Bangladesh needs to pursue entrepreneurial microfinance as well as SMEs.

In Bangladesh the entrepreneurial microfinance through different microfinance programs has come to occupy a central place in poverty-oriented strategies. It has a number of features in common. It mostly aims to serve poor rural women; lend small amounts of money to individuals as members of groups, and rely on group liability for ensuring loan repayment. This can also subsidize the administrative costs rather than interest rates, and loans are repaid generally in weekly installments. Apart from these, poor credit recipients also receive different types of capacity and skill development trainings (Kabeer, 2001).

During the last two decades, hundreds of nongovernment organizations (NGOs) have emerged in Bangladesh with the motivations to support poor rural women by providing collateral free small loans. These NGOs also provide and organize various social services like social mobilization, health care, literacy and education, sanitation, water supply, agriculture, etc. Grameen Bank and BRAC (Bangladesh Rural Advancement Committee) are two of the most successful and the largest NGOs in Bangladesh that have created opportunities for the poor women to become small and medium entrepreneurs. In most of the cases SMEs made positive impacts on the women's socioeconomic lives. However, the mechanism is also not out of criticism. It is not very uncommon that microfinance generates dependency on credit for poor women, and so they are trapped on the credit cycle, creating a new form of dependency and poverty.

This paper highlights a case study from Southwest Bangladesh, where poverty is pervasive, and women are particularly in disadvantaged situations. The critical research question is to investigate how entrepreneurial microfinance is contributing to achieve the targets of UNMDGs locally, and what are the mechanisms of this microfinance program.

\section{STUDY AREA}

The regional focus of this paper is Chuadanga district, which is in the Southwest part of Bangladesh (see Figure 1). District is the smaller local administrative unit of central government. Bangladesh is divided in 64 districts. Chuadanga has an area of $1157.42 \mathrm{sq}$ km (Banglapedia, 2012). 
Figure 1: $\quad$ Chuadanga District

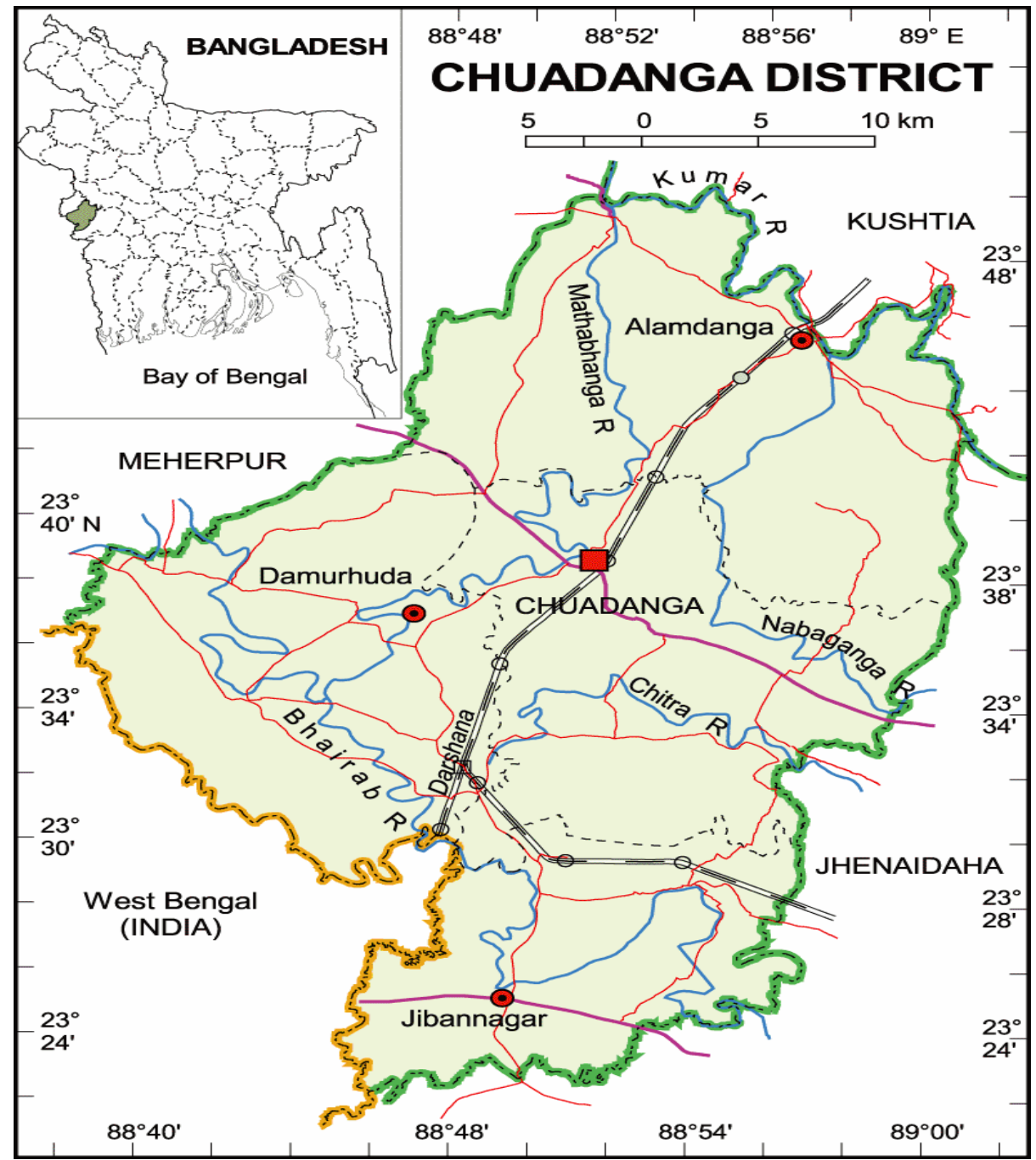

Source: Banglapedia (2012)

One of the major spatial features of this district is that it has an international political border with India, which actually shapes the patterns and features of local economy and economic pattern, particularly for poor women, who are heavily dependent on crossborder smuggling (Nawaz, 2007). There are not much local employment opportunities for the poor women. Education is low among them and very few government services are available to them, so it is not surprising that they are involved with small-scale crossborder smuggling. Usually they smuggle women cloths or salts. They usually have a hard time smuggling when the border security is strict, and without smuggling many have no way of earning income. They get entrapped with hunger and utmost poverty. These poor women usually have a very precarious socioeconomic life, which makes them very 
vulnerable to any forms of uncertainties. To some extent this region also suffers from a spatial poverty trap due to its remoteness, isolation and geographic positions. The major portions of the population are Muslims and partly Hindus. But poverty is relatively severe among the Hindu minorities. Most of the village people are dependent on farms, however, $37 \%$ of them are landless or the marginal farmers. They have very limited access to modern agriculture technologies.

These districts or regions have multiple development barriers, such as local, regional, social, economic or even structural. Government officials believe that they might not be able to achieve regional development targets due to the region's backwardness. In this context, it is interesting to see how the region is behaving with the presence of entrepreneurial microfinance. These two contrasting scenarios therefore contribute to make this region a worthwhile study area for this type of research.

\section{PROJECT DESCRIPTION}

Like many other low-income countries in the global South, Bangladesh also faces challenges to provide sufficient financial and institutional supports to its poor citizens. Therefore NGO initiatives emerged as a response to this development gap. NGO initiatives became visible at the birth of Bangladesh in 1971, when the country was severely devastated during its' liberation war. Reconstruction and humanitarian efforts were the initial agenda for the NGOs. However, at that time there were almost no national NGOs. Most of the visible NGOs were international humanitarian NGOs. Grameen Bank or BRAC formed by the early 1970s with the same agenda as international humanitarian agencies. Slowly national NGOs became involved with different forms of development works. But the contemporary criticisms highlights that NGOs are mostly interested to work with the moderate poor, who have least collateral or who have some forms of collateral to pay back the loan. The question arises then who and how will work for and with the extremely poor people, who have no forms of collateral. In places like in Chuadanga a major share of poor people are extremely poor, and usually they don't get any access to traditional NGOs' services. Here the definitions of moderate and extreme poor follow the international standards: moderate are those who earn more than 2 USD in a day and extreme are those who earn less than 2 USD a day respectively. However, local people distinguish categories of poor people by their food security status: those who can eat twice a day are moderately poor and those who cannot afford even that are extremely poor (Dietzel, 2006).

Jagorani Chakra Foundation (JCF) is one of the very few national NGOs in Southwest Bangladesh, which works with the poorest segment of society, extremely poor women. Project funding comes from a non-profit German organization "NETZ e.V.Partnershaft fuer Entwicklung u. Gerechtigkeit" (in Eng.: NETZ Partnership for Development and Justice). This German organization has been working in Bangladesh with several local NGOs since 1989. Their working philosophy is not to prescribe solutions to the people to get away from the poverty, but instead to support and encourage the initiatives of the underprivileged and their true will for meaningful and lasting change. 
The name of the project is 'Extreme Poor Women's Development Project' (EPWDP), and it involves different types of capacity building trainings with different objectives and contents. The ultimate goal is to increase the entrepreneurial capacity of extremely poor women and to empower them socially, economically and politically. As a whole the projects goals are very much similar to the targets of UNMDG.

The project itself was divided into two phases: First phase (From 2002 to 2006) aimed to help the 3,300 poor women, who are particularly extremely poor. However, in most of these cases, female-headed households without any other income earner, poor, disabled and the poor from ethnic minorities were included in the target groups. Apart from developing entrepreneurial capacities, the goal was also to improve their living condition by developing strong and self-sustaining Community Based Organizations (CBO). In the local understanding, $\mathrm{CBO}$ are the building structures, which are expected to be the center for all women's social \& entrepreneurial knowledge-sharing platforms. Second phase was the consolidation phase (3 years from 2006 to 2009) - inclusion of at least 1,650 additional extremely poor women in total of 4,950 women in the established $33 \mathrm{CBO}$, and sustained with the process of institutional as well as individual level capacity building, so that even after the phase out, they women can sustain with their CBO and can share their knowledge on different aspects of their lives and challenges.

This project involved different components such as a) normal credits, b) flexible credits, c) sanitation credits, d) different types of capacity building programs, and e) risks fund. Brief discussions on these types of products are given below:

a. Normal credits are those credit amounts that were distributed among the women for initiating different forms of entrepreneurial activities. JCF used to charge $10 \%$ interest rate on the overall distributed capital money. According to JCF's, $4 \%$ interest rate is used for maintaining the administrative cost, such as office maintenance, and staff salary, and 5\% interest rate is used for service charge and adjustment with national inflation and rest $1 \%$ was reserved by JCF as part of $\mathrm{r}$ 'Risk Fund'. Risk Fund is very much similar to micro-insurance concept, which is now becoming popular in different parts of the Global South.

b. Flexible Credits were new innovative credit products designed by JCF and NETZ. These products aimed for those extremely poor and vulnerable women, who didn't agree to participate with any NGO microfinance programs due to the fear of weekly repayment. Within the framework of flexible credit, women didn't get any money in their hand, rather one JCF field staff used to go with the women to the market to buy any livestock; in most of the cases, their preference was for a cow. However, they could also choose goats, if they wished. After one year of maintaining that cow (or goat), the women could sell them and earn with some profits. Then the women would pay back the capital money along with $10 \%$ interest. In most of the cases, the women can sell at least at double price. JCF provided them with relevant types of support trainings. But if in any case, there was any damage, such as the death of that animal, JCF refunded by buying another animal. The women didn't pay anything for this. JCF named this concept as 'Asset Transfer Model'. 
c. 'Sanitation Credit' was interest free credit with the aim to make access to the poor to hygienic sanitary facilities. In rural localities, most of the poor households usually have unhygienic sanitary situations. In most of the cases they can't afford the hygienic toilet, and they were not aware about the health hazards of unhygienic toilets. JCF encouraged the poor beneficiary women to avail themselves of this opportunity. The beneficiary women did not need to pay any cost for installation. Participating women who took 100 Taka $(70$ Taka $=1$ US\$) as sanitation credit needed to pay the 2 Taka per week. So if anyone took 500 Taka as sanitation credit, then the beneficiary woman needed to pay ( $2 * 5 \mathrm{Taka})$ 10 Taka per week. This was actually additional money that the beneficiary women needed to pay back with her regular credit returns. Sanitation credit was interest free.

d. Capacity building programs and skill development trainings were provided by JCF to ensure increased capacity of employment and overall empowerment. The spatial selection of any specific training depended on the choices of the beneficiaries based on the needs assessment of that specific location.

e. Risk Funds are provided by JCF for use in any emergency situation, such as floods or losses in crops due to heavy monsoon rains. This was a type of microinsurance for poor women. However, in reality, availability of this fund was not very easy. The financial sources of 'risk funds' come from the women's contribution through weekly interest and JCF contributions in emergency cases.

At the first phase of the project the approximate number of beneficiaries was 3300 extremely poor women. 33 CBO were initially developed and the spatial locations of these CBO were decided based on the patterns of clients' spatial distribution. In usual cases, 12-15 women initially formed a group, as this was a group-based initiative, which is quite similar to traditional micro-finance institutions (MFI). But on the contrary to other MFI, this project is a CBO focused initiative and usually 5-9 groups form a CBO. Major concentration of project beneficiaries were near the border region (1-4 kilometers), which actually demonstrates JCF's intention to work with and work for the extremely poor and vulnerable women and community. In the community, however, it is not possible for all women to take part with project activities or supports, as the number of extremely poor women is much higher than the institutional and financial capacities of JCF or NETZ. They actually followed a logical selection procedure for identifying the really socially and economically deprived and vulnerable women. The women who met the criteria for participation in this project were mostly those who had no cultivatable land or saleable assets and often are the sole provider of their families with a very small or irregular income. Food insecurity was a common phenomenon among the project beneficiaries.

Apart from this project, there were also some other NGOs, more particularly, BRAC (Bangladesh Rural Advancement Committee), ASA (Association for Social Advancement), Caritas, Grameen Bank, Janakallayan, Palli Unnayan Sangsstha (Rural Development Organization, in English), Pratyasha, Srijani, WAVE (Welfare Association for Village Environment), Usha and Intercooperation were active with the local people, 
with the broader agenda of poverty reduction, increased employability and local economic development. However, most of them had no project particularly for extremely poor women in the specific area; rather they were focused on the moderately poor women.

The beneficiary women of JCF's project EPWDP were closely involved with the annual planning, implementation and monitoring of the entire project. Representatives from local government and local people were also aware about JCF's involvements through different organized activities. By regulations, JCF sent each month their program update and outputs to the local government representative and NETZ Country Office in Dhaka (Bangladesh) as well as NETZ Headquarter (HQ) in Germany. So Government and NETZ HQ are also informed with the progress of field activities.

\section{RESEARCH QUESTIONS AND METHODS}

This research aimed to focus on two parallel issues: (1) how entrepreneurial microfinance works in a difficult situation when the community is excessively poor and the region suffers from the spatial poverty trap, and (2) how entrepreneurial microfinance contributed to achieve the targets of UNMDG in this situation.

To address these research questions, two types of data were collected: (1) primary data, and (2) secondary data. Then each type of data was divided into two categories, such as (a) qualitative data and (b) quantitative data. The details of the data patterns are as follows:

\section{(1) Primary Data:}

a. Qualitative Data: The qualitative data were collected from the field discussion and interviews without any structured questionnaire. The inputs were enormous. The qualitative information gave an idea about several socio-cultural aspects of regional features, such as what are the reasons of regional poverty and why it matters for the women and what they would do if they get more financing.

Several Group discussions along with discussions with single women were organized during the field research to identify the major feature of local poverty, with special emphasis on gender aspects. To identify the effectiveness of the JCF microcredit and support program in the local context, several PRA (Participatory Rural Appraisals) were also conducted among beneficiary women. In different times and in different places, informal discussions were also conducted with local people (men and women, who are not the beneficiaries of JCF Program) about their thoughts regarding local employability and economy. This information was useful in different steps of the field research and report writing. Without this acquired background information, it would be almost impossible to identify the background reasons of poverty and how JCF projects can contribute to achieve the targets of UNMDG.

b. Quantitative Data: The quantitative data were acquired from close-ended questionnaires. There were attempts to get information on various socio- 
economic aspects through close-ended questionnaire. Final intention was to analyze this information to have a clear observation of the local scenarios.

\section{(2) Secondary Data:}

a. Qualitative Data: During the field research, several structured and unstructured interviews were done with concerned local experts on microfinance and rural development. These discussions helped to identify the relevant literatures and also contributed to develop research arguments and methodologies.

b. Quantitative Data: Secondary quantitative data and information were also used in this research work. For example, Jagorani Chakra along with NETZ Country Office conducted baseline surveys to identify the beneficiaries and to survey the "entire poverty scenario".

However, to conduct the questionnaire survey (collection of primary data: quantitative), the interviews were done with the beneficiary women. 5\% women were taken as sample for the interview. The women were selected by following some systematic procedures, such as their level of income, their engagement with the JCF project, their location and their religious identity. In most of the cases the attempt was to avoid any forms of selection biases of the sample women. However, in some situations, few women were selected randomly, as they were identified as exceptional or interesting cases for this research.

\section{FINDINGS}

It is always a challenge for the countries like Bangladesh to achieve major national and international development targets. Entrepreneurial microfinance programs are not rare in Bangladesh. But very few researches have yet addressed how entrepreneurial microfinance has contributed to achieve the targets of UNMDG. The UNMDG comprises 8 major goals: (1) End Poverty and Hunger, (2) Universal Education, (3) Gender Equality, (4) Child Health, (5) Maternal Health, (6) Combat_HIV/AIDS, (7) Environmental Sustainability, and (8) Global Partnership. Detailed discussions of how entrepreneurial microfinance can contribute to achieve these goals are given below:

\section{MDG 1: Eradicate Poverty and Hunger}

Target: Halve, between 1990 and 2015, the proportion of people whose income is lesser than $\$ 1$ a day.

Bangladesh must reduce the proportion of population with income less than one US dollar (PPP) a day from 58.8\% in 1990 to $29.4 \%$ by 2015 if Bangladesh wants to achieve the MDG 1(UNDP, 2010a). However, Bangladesh, especially the Southwest part, will not achieve the targets by the desired timeline unless there are some additional interventions (UNDP, 2010b). In this context, projects like EPWDP contributed directly to reduce extreme poverty by improving the income of poor women. Previously in the EPWDP area, most extremely poor women were involved only in household work or in some illegal work such as smuggling. But after, with the JCF project involvement, they have 
engaged in different forms of wage employments along with different SME, like cattle rearing, small village shops and handicrafts. These entrepreneurial activities indicated women's increased income and confidence and engagement with mainstream economic activities. The women reported that $96 \%$ of their investments were successful and profitworthy.

However, the average income has also increased over the time. Average income increased by $22 \%$ in 2009 compared to 2006 value. Considering the per capita income per month, $8.7 \%$ beneficiaries have passed over the international poverty line of income per capita per month 1,125 Taka ( 1 US\$=70 Taka). Additionally the savings have also increased.

\section{Figure 2: $\quad$ Savings among the Beneficiary Women}

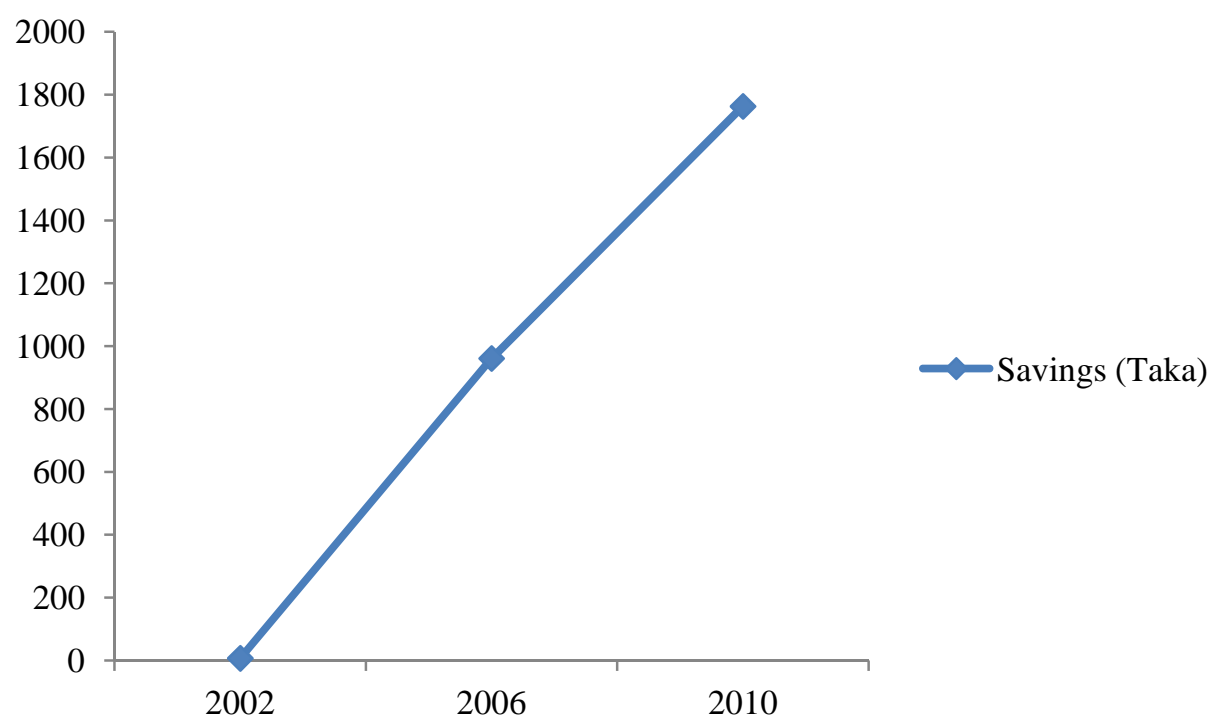

These types of income-related outcomes have also been confirmed by PanjaitanDrioadisuryo and Cloud (1999), who identified Bank Rakyat Indonesia (BRI) clients' incomes increased by $112 \%$. This income increase helped the poor women to move above the poverty line. In People's Republic of China (PRC), microfinance programs have helped lift 150 million people out of poverty since 1990 (United Nations, 2005). It has been proved that the beneficiaries of microfinance, who mostly invested their credits as well as their savings to different types of SME, and had the opportunity to shift from precarious, low-paid daily jobs to more secured employment (Simanowitz, 2003; Zaman, 2000).

EPWDP opens the avenue for the poor rural women to engage themselves in different types of farm and non-farm activities. These types of engagements enhance the chances of employability and on the other hand ensure local food security.

Regionally Chuadanga district suffers food insecurity problems. When this EPWDP was started, $99 \%$ of beneficiaries took meals 2 times per day and 1\% took 1 meal per day. 
After 1 year, 47\% beneficiary women took meals 3 times per day and only 53\% could take meals 2 times a day. By mid-2007, 50\% of microfinance members could eat more sufficient meals per day than before. However by 2009, all the members were able to secure three meals a day. This was a remarkable improvement regarding local food security. In another similar study Chowdhury and Bhuiya (2000) explained that usually microfinance borrowers suffer less from severe malnutrition (relative to the control group), and the extent of severe malnutrition declined as the length of membership increased.

\section{MDG 2: Achieve Universal Primary Education}

Development regarding MDG 2, universal education, is based on a comparison of poor women before enrolling in the project and after enrolling in the project. It is clear that beneficiary women are more aware and keen to send their children to the school than before entering the program. As well, women who were fully illiterate, could neither read nor write, or even could not sign their own name, showed remarkable progress. Due to their microfinance activities and related management works, they learned how to calculate small amounts of money, along with signing their names. The children of EPWDP beneficiary women were likelier to attend and stay in school longer. Student drop-out rates were also much lower than the other poor rural families.

Figure 3: $\quad$ Present Educational Status of the Family Members

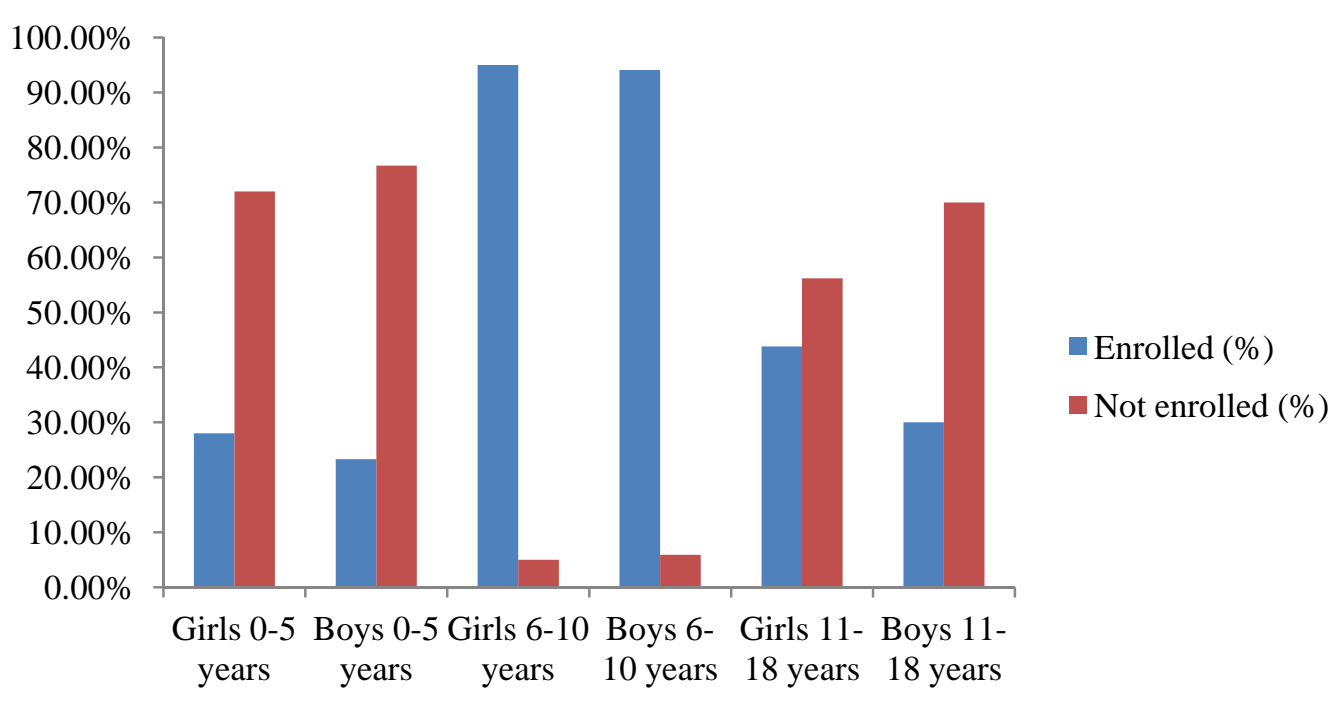

Greater access to financial services and increased incomes allow poor people to invest on their children's future. 


\section{MDG 3: Gender Equality and Women's Empowerment}

The abilities to borrow, save, and earn enhances poor women's confidence by enabling them to better confront systemic gender inequities. CGAP (2002) highlights different forms of empowerment across regions: a) in Indonesia, female beneficiaries of BRI were more likely than non-clients in the position to make joint decisions with their husbands concerning allocation of household money, children's education, use of contraceptives and family size etc.; b) in Nepal, 68\% of Women's Empowerment Program members mentioned that they take their decisions on buying or selling property, sending daughters to school or family planning; c) in India, SEWA clients have lobbied for higher wages, the rights of women in the informal sector, and resolving neighborhood issues; and d) in Bangladesh, Bolivia, Nepal, the Philippines and Russia, clients of microfinance programs have run even for local government office and won.

Similarly, at this EPWDP, the beneficiary women get skills or capacity building trainings that help them not only to develop their entrepreneurship or entrepreneurial capacities, but also prepare them for the lasting development. These trainings are quite versatile in nature and address different components of empowerment and gender equality.

\section{Figure 4: Offered Capacity Building Trainings}

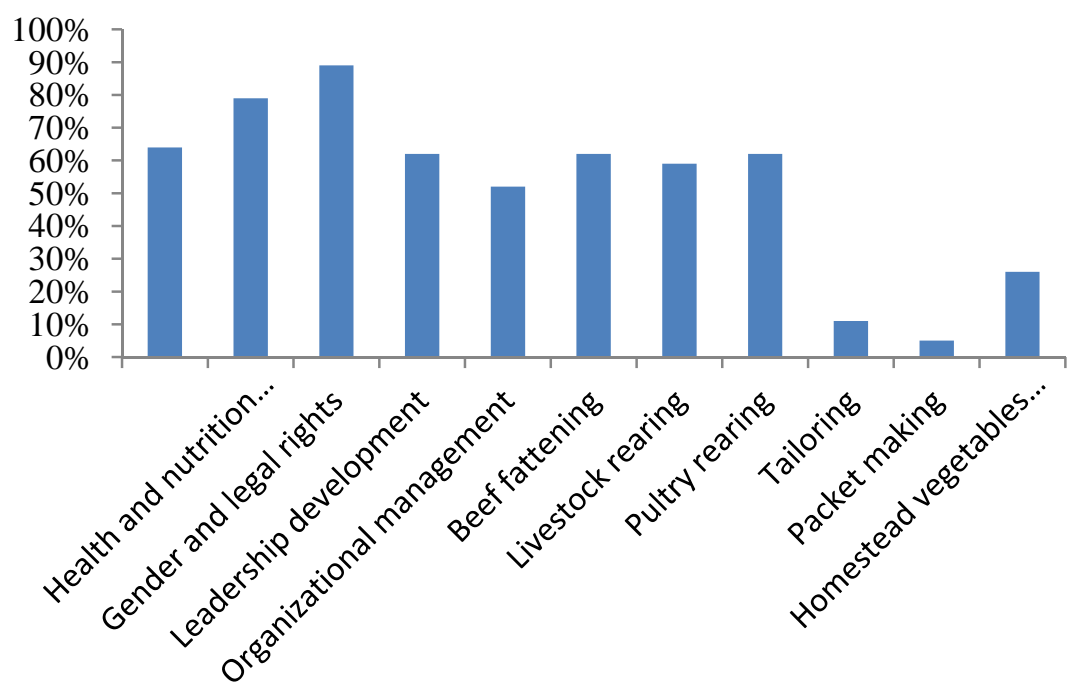

These types of skill development trainings and opportunities have direct positive impacts on the women's empowerment. In addition to this, these trainings also help to develop women's shock resiliency in response to unprecedented crises or vulnerabilities. 
Figure 5: Usefulness of Received Capacity Development Trainings

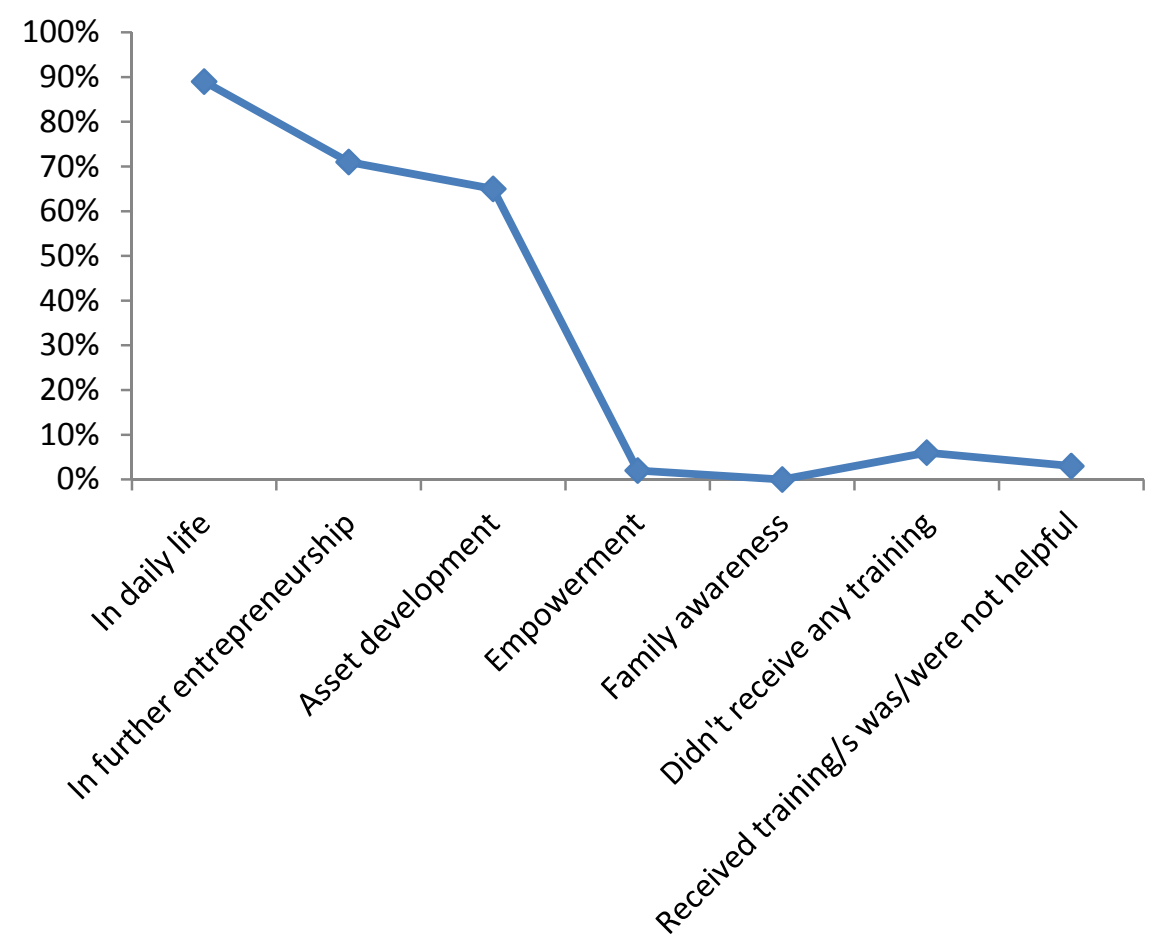

Skill development trainings and opportunities contributed in the JCF project area to develop social capital, awareness, peer-group mentoring and enhanced employment capacity.

\section{MDGs 4, 5 \& 6: Reduce Child Mortality; Improve Maternal Health; and Combat HIV/AIDS, Malaria, and Other Diseases}

Child mortality and maternal health are among some of the major development challenges in Bangladesh, and the government has taken these issues very seriously. In recent years, there has been some demonstrable progress, even though outcomes vary across regions, communities, ethnic or minority groups. The maternal mortality ratio should be reduced by three-quarters between 1990 and 2015, if Bangladesh is to achieve the MDGs 4, 5 \& 6. Vaccination is one of the major initiatives to reduce mother and child mortalities. In the EPWDP out of 312 eligible cases pregnancy, 83\% mothers were vaccinated while $17 \%$ mothers were not vaccinated. Many of the components of MDG 4, 5 and 6 are closely interlinked with improved food security, increased income, access to health services and awareness. JCF EPWDP participants have appeared to have better nutrition, living conditions, and preventive healthcare than comparable non-participant women. 


\section{MDG 7: Ensure Environmental Sustainability}

Sanitation credit was an innovative concept of JCF, and this was also an important component of the entire project. Sanitation credit directly contributes to achieve the UNMDG 7.

In rural Bangladesh, the predominant sources of drinking water are tube-wells, and these are often identified as the safe drinking water sources. In the project areas and among the beneficiaries, access to safe drinking water was $100 \%$. The improved sanitation among the beneficiary households is evident from the fact that more than 4/5th of the households (82\%) were using hygienic latrines against $9 \%$ in 2002 and $80 \%$ in 2006, $17 \%$ are using unhygienic latrines against $24 \%$ in 2002 and $16 \%$ in 2006. In addition, still $1 \%$ families are defecating in open places behind bushes or banks of the rivers compared to $67 \%$ in 2002 and $0.5 \%$ in 2006.

\section{MDGs 8: Develop a Global Partnership for Development}

Providing financial services to the poor and development cooperation are some of the major components of MDG 8. In the local context, EPWDP was the key to development of microenterprise operated by extremely poor women. JCF services allow the poor to produce products for the market. Very often, these products are sold in extra-local markets and therefore, in a way, entrepreneurial microfinance enhances global and regional partnership for development.

\section{CRITICISMS}

Most of the NGO that work with microfinance are not immune to criticism. However, microfinance participants have experienced several generations of improvement. NGO programs have moved from microcredit, where the poor were given only interest-bearing credit to microfinance. Participants now receive trainings to use credit. This concept got further improvement and it turned into micro-financial services, where poor people were offered not only credits or skill development trainings, but also services like microinsurance or awareness trainings for their rights to services. Right now in many parts of the Global South, this development product is known as rural financial services, where poor people get credit, training, supports (i.e. legal or health) and also are offered supports within the bigger framework of inclusive development strategy at the local and regional level.

Critics of microfinance might assume that EPWDP created some forms of dependency among extremely poor women by continuous dependency on JCF credits or services. In addition to this, there were also some other areas of concern, such as: (a) weekly repayment schedule started usually a week after a credit was taken; (b) sometimes savings among the beneficiary extreme poor women were not sufficient for their SME development; (c) developing the capacity was never a linear process for every woman, e.g. the capacity to receive knowledge or to develop skills differs from person to person; (d) lack of motivations to participate in the offered training programs; (e) underutilization and mishandling of credit amounts by beneficiaries or project staffs. 
In addition, EPWDP also suffered from several types of risks, such as probabilities of harmful consequences or unexpected losses (deaths, injuries, property, livelihoods, economic activity disrupted or environmental damaged) resulting from the interactions between natural or human induced hazards and vulnerable conditions. It was not certain whether the women could develop themselves within that time frame with proper management and leadership capacities. Nevertheless women always faced societal risks due to the strict attitude of religion and local conservative rural culture regarding the interactions with others except their family members.

\section{SUMMARY}

JCF entrepreneurial microfinance demonstrates how development innovations can contribute to achieve the overarching UNMDG. UNMDG as a development framework are now an integral part of National Annual Development Plans in Bangladesh. Without an innovative development approach, it will be difficult to achieve sustainable levels of human development among extremely poor women. The JCF project is subject to numerous criticisms and is not in perfect shape. This project as well as approach might go further with a number of refinements or improvements so that people can experience the benefits more holistically.

This research addresses how to improve the quality of life and wellbeing of extremely poor women in a particular region that already suffers from a spatial poverty trap. JCF projects address the real and perceived social injustices and in some way the violations of basic human rights. In the case of Bangladesh, the state has failed due to its limited financial and institutional capacity to ensure those basic human rights to its citizens. Therefore, this project can be identified as a rights-based approach to development in the rural community. Welfare and services are at the core of this concept. The work conducted by JCF, which included theories from different social science disciplines, demonstrates how to implement those theories into practice.

Different components of poverty influence each other in a typical rural community in Bangladesh. This intra influence creates a spiral of insecurity, which produces multiple deprivations. Deprivations usually begin with the loss of employment, which in turn leads to a significant degradation in living standards. This ultimately increases the risks of poverty and impoverishment. Living in poverty creates additional difficulties in the search for employment and contributes to a long-term unemployment trap for many individuals. Concurrence of unemployment and poverty are some of the major obstacles for victimized persons regarding their participation in social activities. Due to the lack of money and social stigmas, social ties are weakened and that increases the risks of being socially isolated. Extremely poor woman in the rural Bangladesh are a precise example of this phenomenon.

No single intervention can defeat poverty. Therefore a continuous process of development innovation is necessary. Poor people need employment, trainings, skills, schooling, and health care or some additional livelihoods supports. Some extremely poor women might require immediate income transfers or relief to survive. This is not an exceptional phenomenon only in the Global South. More developed societies also have 
similar challenges. Access to financial services and thereby entrepreneurship development, form the fundamental basis on which many of the other essential interventions depend. Moreover, in practical situations, improvements in health care, nutritional advice and education can be sustained only when households have increased earnings and have greater access and control over financial resources. Financial services, such as entrepreneurial microfinance thus reduce poverty and meaningfully contribute to reach the targets of UNMDG, which are some of the major policy targets to ensure human development. However, even though there are some mixed experiences regarding the role of microfinance on entrepreneurship development and their combined impacts on achieving the UNMDG, there is clear evidence from the findings that JCF projects and social commitments have enormous impact on the socioeconomic empowerment of extremely poor women. Conceptually the project might have relevance in other parts of the world with similar socioeconomic context and challenges.

\section{References}

Adams, J., \& Raymond, F. (2008). Did Yunus deserve the Nobel Peace Prize: Microfinance or macrofarce? Journal of Economic Issues, 42(2), 435-443.

Banglapedia. (2012) Chuadanga District. Retrieved from http://www.banglapedia.org/httpdocs/HT/C 0260.HTM

CGAP. (2002). Helping to Improve Donor Effectiveness in Microfinance: Microfinance and the Millennium Development Goals. Retrieved from http://www.cgap.org/gm/document-1.9.2422/DonorBrief_09.pdf

Chowdhury, A.M.R., \& Bhuiya, A. (2000). Do poverty alleviation programmes reduce inequality in health: The Bangladesh experience. In D. Leon \& G. Walt (Eds.), Poverty, inequality and health (pp. 312-332). Oxford: Oxford University Press.

Dietzel, P. (2006): Ein Leben lang genug Reis. In P. Hesse (Ed.), Solidarität die ankommt - Ziel effizienteMittelverwendung in der Entwicklungszusammenarbeit. Hamburg: Global Marshal Plan Initiative.

Kabeer, N. (2001). Conflicts over credit: Re-evaluating the empowerment potential of loans to women in rural Bangladesh. World Development, 29(1), 63-84.

McKenzie, D. J., \& Woodruff, C. (2006). Do entry costs provide an empirical basis for poverty traps? Evidence from Mexican microenterprises. Economic Development and Cultural Change, 55(1), 3-42.

Nawaz, K. M. (2007). Interview at the Jagorani Chakra Foundation Office in Darsana, Chuadanga at 09 April, 2007.

Panjaitan-Drioadisuryo, R. D. M., \& Cloud, K. (1999). Gender, self-employment and microcredit programs: An Indonesian case study. The Quarterly Review of Economics and Finance, 39, 769-79.

Pimple, M. (2009). The Millennium Development Goals and Microfinance: National Conference on Microfinance and Millennium Development Goals. Retrieved from 
http://www.endpoverty2015.org/files/MDG\%20and\%20Microfinance 22 Aug\%202 $\underline{009 \text { 0.pdf }}$

Simanowitz, A. (2003). Appraising the Poverty Outreach of Microfinance: A Review of the CGAP Poverty Assessment Tool (PAT). Retrieved from http://ageconsearch.umn.edu/bitstream/23743/1/op030001.pdf

Ssewamala, F. M., Lombe, M., \& Curley, J. M. (2006). Using individual development accounts for microenterprise development. Journal of Developmental Entrepreneurship, 11(2), 117-131.

Tokman, V. (1996). Regulation and the informal economy: Micro-enterprises in Chile, Ecuador, and Jamaica. Boulder: Lynne Rienner Publishers.

United Nations. (2005). UN Human Development Report 2005. New York: Author.

United Nations Development Programme. (2010a). Bangladesh. A Baseline for Needs Assessment and Costing. A Situation Analysis Report on Poverty and Hunger (MDG 1). Retrieved from http://www.undp.org.bd/projects/prodocs/PRS_MDG/Situation\%20analysis_poverty \%20and\%20Hunger.pdf

United National Development Programme. (2010b). Bangladesh. A Baseline for Needs Assessment and Costing. A Situation Analysis Report on Health (MDG 4,5 and 6). Retrieved from http://www.undp.org.bd/projects/prodocs/PRS_MDG/Situation\%20analysis_health.p df

Varghese, A. (2005). Bank-moneylender linkage as an alternative to bank competition in rural credit markets. Oxford Economic Papers, 57(2), 315-335.

Zaman, H. (2000). Assessing the Poverty and Vulnerability Impact of Micro-Credit in Bangladesh: A Case Study of BRAC. Retrieved from http://wwwwds.worldbank.org/external/default/WDSContentServer/IW3P/IB/1999/09/10/00009 4946_99082405303974/Rendered/PDF/multi_page.pdf

\section{Author note:}

Address correspondence to: Saleh Ahmed, Ph.D. Student, Department of Sociology, Social Work \& Anthropology, Utah State University, 0730 Old Main Hill, Logan, UT 84322-0730. E-mail: saleh.ahmed@aggiemail.usu.edu 